\title{
PENGARUH LAYANAN BIMBINGAN KELOMPOK TERHADAP KETERLIBATAN AKADEMIK PADA SISWA YATIM ATAU PIATU DI SMA NEGERI 2 KOTA BENGKULU
}

\author{
Dewi Citra Anggraini, Hadiwinarto, Afifatus Sholihah \\ Prodi Bimbingan dan Konseling Fakultas Keguruan dan Ilmu Pendidikan \\ Universitas Bengkulu \\ Dewicitraa09@gmail.com, Hadiwin@unib.ac.id, afifatus@unib.ac.id
}

\begin{abstract}
ABSTRAK
Penelitian ini bertujuan untuk mendeskripsikan pengaruh layanan bimbingan kelompok terhadap keterlibatan akademik pada siswa yatim atau piatu. Metode penelitian ini adalah eksperimen dengan dessain penelitian One group pre-test dan post-testdesign. Subjek penelitian ini adalah 10 Orang siswa. Teknik pengumpulan data menggunakan angket. Sedangkan uji analisis data menggunakan $U j i-z$. Hasil penelitian ini menunjukkan adanya pengaruh layanan bimbingan kelompok terhadap keterlibatan akademik pada siswa yatim atau piatu. Hal ini dilihat dari meanpre-test $=69$ dan mean post-test $=94$ dengan nilai $z=-$ 2,805 dan $\mathrm{p}<0,05$. Artinya ada perbedaan yang signifikan setelah diberikan layanan bimbingan kelompok.
\end{abstract}

Kata kunci : keterlibatan akademik pada siswa yatim atau piatu dan layanan bimbingan kelompok

\section{THE INFLUENCE OF GROUP CONSELING SERVICE ON THE ACADEMIC INVOLVEMENT OF ORPHANED STUDENTS IN SMA NEGERI 2 KOTA BENGKULU}

\begin{abstract}
The aimed of this study was see the influence of group counseling service on the academic involvemennt of orphaned students. The method of this research was experiment with one gorup pree-test and post-test research design. The subject of this research was 10 students. Questionnaires were used in collecting the data. While date analysis test using uji-z. The result of this research showed that there were academic involvements on the orphaned student. It can be seen from the pree-test mean 69 and the post-test mean 94 with $\mathrm{z}$ score 2,805 and $p<0,05$. It means that there were significant improvements after being given group conseling service.
\end{abstract}

Keywords : academic involvement on the orphanes students and group counseling service 


\section{Pendahuluan}

Tujuan belajar adalah ingin mendapatkan pengetahuan, keterampilan, dan penanaman sikap mental dan nilai. Pencapaian tujuan belajar berarti menghasilkan hasil belajar (Sardiman, 2011: 28). Hasil belajar siswa akan optimal apabila siswa terlibat dalam kegiatan akademik di sekolah. Aktivitas diperlukan dalam belajar, karena pada prinsipnya belajar adalah berbuat. Berbuat untuk mengubah tingkah laku, jadi melakukan kegiatan. Menurut Sardiman (2011: 95), tidak ada belajar kalau tidak ada aktivitas. Sedangkan kesuksesan akademik siswa sangat ditentukan oleh siswa itu sendiri sebagai subjek yang mengalami proses belajar, yang akan mengalami perubahan perilaku (Dharmayana, 2012: 77).

Keluarga merupakan tempat utama bagi anak dalam menjalani proses tumbuh dan berkembang. Orang tua memiliki peran yang sangat penting dalam mendampingi proses perkembangan anak. Oleh karena itu keutuhan keluarga dibutuhkan dalam proses perkembangan. Keutuhan keluarga adalah keutuhan dalam struktur keluarga, yaitu bahwa keluarga terdiri atas, ayah, ibu, dan anak-anak. Selain dibutuhkan dalam interaksi keluarga, bahwa di dalam keluarga berlangsung interaksi sosial yang harmonis (Gerungan, 2004 : 199).

Keutuhan keluarga merupakan hadirnya ayah, ibu dan anak dalam satu keluarga. Apabila ayah atau ibunya jarang pulang ke rumah karena tugas di luar rumah, dan terjadi berulang-ulang atau apabila orang-tua bercerai, semua ini akan mempengaruhi keutuhan/kesatuan dalam keluarga. Selain keutuhan keluarga, interaksi antara anggota keluarga yaitu berupa hubungan harmonis di dalam keluarga memegang peran penting dalam perkembangan sosial anak. Ketidak-utuhan keluarga dapat menghambat perkembangan sosial dan interaksi anak (Noorkasiani dkk, 2009: 152).

Asmani (2010: 277), peran keluarga sangat penting, mengetahui dan memahami karekter, kebiasaan, dan perilaku anak sehari-hari, yang baik dan yang jelek. Semua kegiatan yang terjadi di dalam keluarga akan selalu diingat oleh anggota keluarga dengan menyimpannya di dalam memori otak. Untuk itu peristiwa yang menyenangkan di dalam keluarga akan sangat di kenang oleh satu sama lain.

Tohirin (2015: 164) layanan bimbingan kelompok merupakan suatu cara memberikan bantuan dan bimbingan kepada siswa melalui kegiatan kelompok. Dalam layanan bimbingan kelompok, aktivitas, dan dinamika kelompok harus diwujudkan untuk membahas berbagai hal yang berguna bagi pengembangan atau pemecahan masalah siswa yang menjadi peserta layanan. 
Berdasarkan hasil pengamatan peneliti saat Magang 3 selama kurang lebih 3 bulan di SMAN 2 Kota Bengkulu, dari total keseluruhan siswa kelas satu ada beberapa siswa yatim tau piatu yang kurang akan motivasi dan minat dalam belajar dan perhatian yang diberikan guru sehingga membuat siswa tidak ada semangat mengikuti pembelajaran di sekolah sehinga nilai akademiknya rendah, membuat siswa yatim atau piatu memilki keterlibatan akademik belajar yang rendah, dan peran keluarga sangat diperlukan guna untuk membantu siswa menangani masalah berkaitan dengan akademik siswa disekolah.

Berdasarkan latar belakang tersebut, dapat dirumuskan permasalah dalam penelitian ini adalah sebagai berikut :

1. Bagaimana keterlibatan akademik siswa yatim atau piatu sebelumdiberikan layanan bimbingan kelompok di SMA Negeri 2 Kota Bengkulu?

2. Bagaimana keterlibatan akademik siswa yatim atau piatu sesudah diberikan layanan bimbingan kelompok di SMA Negeri 2 Kota Bengkulu?

3. Bagaimana perbedaan tingkat keterlibatan akademik siswa yatim atau piatusebelum dan sesudah dilakukan bimbingan kelompok di SMA Negeri 2 Kota Bengkulu?

4. Bagaimana pengaruh layanan bimbingan kelompok terhadap keterlibatan akdemik siswa di SMA Negeri 2 Kota Bengkulu?

\section{Metode Penelitian}

Desain penelitian yang digunakan peneliti adalah desain penelitian eksperimen dengan jenis one group pre-test post-test design. Rancangan eksperimen one group pre-test post-test design adalah suatu teknik untuk mengetahui efek sebelum dan sesudah pemberian perlakuan.Populasi dalam penelitian ini sebanyak 16 siswa dan sampel penelitian sebanyak 10 siswa, alat pengumpulan data yang digunakan adalah instrumen angket.

Sugiyono (2009: 61), populasi adalah wilayah generalisasi yang terdiri dari atas: obyek/subyek yang mempunyai kualitas dan karekteristik terntentu yang ditetapkan oleh peneliti untuk dipelajari dan kemudian ditarik kesimpulannya. Sedangkan menurut Zuriah (2009: 116), populasi adalah seluruh data yang menjadi perhatian penelitian dalam suatu ruang lingkup dan waktu yang ditentukan.

\section{Hasil dan Pembahasan}

Pada Penelitian ini terdiri data variabel yaitu satu variabel terikat keterlibatan akademik, serta variabel bebas layanan bimbingan kelompok yang dilakukan pada siswa 
yatim atau piatu di SMA Negeri 2 Kota Bengkulu. Pada pembahasan berikut akan dideskripsikan data dari masing-masing variabel, di antaranya mean, median, modus dan standar deviasi, selain itu akan dipaparkan juga tentang tabel deskripsi data. Berikut ini merupakan rincian dari hasil pengolahan data yang telah dilakukan dengan menggunakan bantuan program SPSS 17.

Sebelum melakukan pertemuan pemberian materi layanan, maka dilakukan pengambilan data pre-testterhadap siswa yatim atau piatu. Pengambilan data awal ini dilakukan pada tanggal 17 April 2018. Pada hari yang sama, setelah melakukan pre-test juga dilakukan penyampaian maksud dan tujuan penelitian kepada peserta didik.

Setelah semua kegiatan layanan bimbingan kelompok dilaksanakan dan diakhiri pada tanggal 4 Mei 2018, maka keesokan harinya langsung dilakukan pengambilan data akhir atau post test. Pengambilan data akhir dilakukan kepada 10 siswa yatim atau piatu yang telah mengikuti tahap awal hingga akhir. Setelah pengambilan data dilakukan, langsung dilanjutkan dengan perpisahan dan ucapan terimakasih kepada peserta didik yang terlibat dalam peneltian ini.

Tabel 1

Deskripsi Data Pre-Test

\begin{tabular}{lccc}
\hline Kategori & Rentang Skor & Frekuensi & Persentase \\
\hline Sangat tinggi & $>105$ & & $00 \%$ \\
Tinggi & $85-104$ & 0 & $0 \%$ \\
Sedang & $65-84$ & 9 & $90 \%$ \\
Rendah & $45-64$ & & $110 \%$ \\
Sangat rendah & $<44$ & & $00 \%$ \\
\hline
\end{tabular}

Berdasarkan tabel diatas maka dapat dijelaskan bahwa keterlibatan akademik sebelum diberikan treatmen bimbingan kelompok (pre-test) adalah: Siswa yatim atau piatu dengan keterlibatan akademik pada tingkatan sangat tinggi berjumlah 0 dengan persentase $0 \%$.Siswa yatim atau piatu dengan keterlibatan akademik pada tingkatan tinggi berjumlah 0 siswa dengan persentase $0 \%$. Siswa yatim atau piatu dengan keterlibatan akademik pada tingkatan sendang berjumlah 9 siswa dengan persentase sedang 90\%. Siswa yatim atau piatu dengan keterlibatan akademik pada tingkatan rendah berjumlah 1 siswa dengan persentase 10\%.Siswa yatim atau piatu dengan keterlibatan akademik pada tingkatan sangat rendah berjumlah 0 siswa dengan persentase $0 \%$. 
Setelah dilakukan treatment bimbingan kelompok dengan topik mengenai keterlibatan akademik dengan 6 kali pertemuan yang diberikan kepada siswa yatim atau piatu dengan sampel 10 siswa yatim atau piatu. Siswa yang dibentuk menjadi satu kelompok, selanjutnya dilakukan pengambilan data akhir (post test) dengan memberikan soal tes yang sudah divaliditaskan.

Tabel 1

Deskripsi Data Post-Test

\begin{tabular}{lcc}
\hline Kategori & Sampel & Persentase \\
\hline Sangat tinggi & 2 & $20 \%$ \\
Tinggi & 7 & $70 \%$ \\
Sedang & 1 & $10 \%$
\end{tabular}

Berdasarkan table diatas dapat disimpulkan bahwa 20\% sanggat tinggi, $70 \%$ skor tinggi dan $10 \%$ dengan skor sedang. Instrumen penelitian ini telah melalui tahap uji reliabilitas. Sehingga instumen ini benar-benar telah memenuhi drajat kosistensi sebagai sebuah instrumen yang dapat dipergunakan.Cronbach's Alpha sebesar 0,746 berarti Cronbach's Alpha 0,746 > 0,70 dengan relibiltas baik, sehingga instrumen tersebut memiliki reliabiliti yang tinggi.

Uji Hipotesis dalam penelitian ini adalah menguji pengaruh layanan bimbingan kelompok terhadap keterlibatan akademik pada siswa yatim atau piatu. Dalam uji ini digunakan rumus Z-test yaitu teknik statistik yang digunakan untuk melihat adakah pengaruh layanan bimbingan kelompok sebelum dan sesudah diberikan treatment layanan bimbingan kelompok.

Hasil perhitungan Uji Z taraf signifikan adalah 0,000 lebih kecil dari 0,005. Dapat dipastikan bahwa Ha diterima dan $\mathrm{H} 0$ ditolak. Hal ini sesuai dengan kriteria penerimaan dan penolakan hipotesis. Nilai Z negatif $(-2,805)$ yang menunjukkan bahwa terdapat perbedaan skor dan terjadi peningkatan keterlibatan akademik pada siswa yatim atau piatu setelah diberikan treatmentberupa layanan bimbingan kelompok. Pengaruh layanan bimbingan kelompok dapat dilihat pada nilai rata-rata pre-test dan post test. 


\section{Hasil dan Pembahasan}

Penelitian ini bertujuan untuk melihat pengaruh layanan bimbingan kelompok terhadap keterlibatan akademik pada siswa yatim atau piatu. Sampel penelitian ini dilakukan pada 10 siswa yatim atau piatu, penelitian ini merupakan eksperimen One Group Pre-Test Post-Test.

Sebelum diberikannya layanan bimbingan kelompok, keterlibatan akademik siswa yatim atau piatu dapat dilihat dari skor pre-test post test. Bedasarkan skor pre test terdapat 10 siswa yatim atau piatu yang keterlibatan akademiknya rendah. Hal ini disebabkan oleh kurangnya perhatian kedua orang tua dalam membimbing anak yang menyebabkan anak menjadi malas dan kurang bersemangat dalam mengikuti kegiatan belajar dan mengajar dikelas.

Proses meningkatkan keterlibatan akademik ditunjukkan pada proses pelaksanaan kegiatan bimbingan kelompok. Treatment yang dilakukan sebanyak 6 kali pertemuan. Kegiatan bimbingan kelompok dengan tema Mengenali emosi diri, meningkatkan motivasi belajar, mentaati tata tertib sekolah, membangkitkan minat siswa pada belajar, kebiasaan menunda-nunda tugas, dan konsentrsi dalam belajar.

Berdasarkan skor yang digunakan pre test dan post test, keterlibatan akademik siswa menjadi kategori sangat tinggi, tinggi, sedang, rendah, dan sangat rendah. Terdapat sebanyak 4 orang siswa memiliki keterlibatan akademik tinggi, 4 orang memiliki keterlibatan akademik sedang, 1 orang memilki keterlibatan akademk rendah dan 1 orang memiliki keterlibatan sangat rendah. Hasil pre-test, keterlibatan akademik siswa dengan rata-rata skor 69. Siswa yang telah mengisi angket dan telah mendapatkan hasilnya dan diberikan treatment berupa layanan bimbingan kelompok.

Setelah kegiatan bimbingan kelompok sebanyak 6 kali pertemuan, pemimpin kelompok mengadakan post test kepada anggota kelompok.Keterlibatan akademik siswa yatim atau piatu sesudah diberikannya layanan bimbingan kelompok dengan melihat keterlibatan siswa dalam kegiatan belajar dan mengajar. Berdasarkan hasil post-test, keterlibatan akademik siswa meningkat dengan rata-rata skor 94 dengan kategori sangat tinggi.

Perubahan skor tersebut dikarenakan terjadi pada pelaksanaan layanan bimbingan kelompok dibahas secara detail mengenai keterlibatan akademik siswa dengan tema yang berbeda setiap pertemuan.

Berdasarkan pertemuan pertama sampai dengan pertemuan keenam dapat dianalisis bahwa anggota yang tadinya belum aktif menjadi aktif fan mau untuk berpendapat. Kegiatan 
layanan bimbingan kelompok sudah memahami tema yang yang dibahas pada setiap pertemuan. Anggota kelompok menunjukkan perubahan sikap pada sikap proses kegiatan bimbingan kelompok dan sudah mampu menerapkan hasil bimbingan sebelumnya ke bimbingan kelompok selanjutnya.

Selama pelaksanaan layanan bimbingan kelompok keterlibatan akademik dipengaruhi oleh beberapa aspek yaitu dengan melihat perasaan siswa untuk mengikuti kegiatan belajar dan mengajar dikelas, serta melihat keikut sertaan siswa ikut bersosialisasi.

Hal tersebut sejalan dengan aspek keterlibatan akademik. Menurut Dharmayana, dkk (2012:81) pengertian keterlibatan akademik adalah ukuran keterlibatan siswa dengan sekolah, yaitu suatu proses psikologi yang menunjukkan perhatian, minat, investasi, usaha dan keterlibatan siswa yang dicurahkan dalam pekerjaan belajar di sekolah. Adapun aspek-aspek keterlibatan akademik, Dharmayanan, dkk. (2012:81), adalah:

\section{Keterlibatan Emosi (Emotional Engagement)}

Keterlibatan emosi (emotional engagement)merupakan sesuatu yang mengembangkan konsep ketertarikan. Aspek yang termasuk dalam emotional engagement di antaranya: reaksi positif dan negatif terhadap guru, teman sekolah, akademis atau sekolah, dan menciptakan ikatan dengan sekolah yang akan mempegaruhi motivasi untuk belajar (Fredricks, dkk, 2004: 62).

\section{Keterlibatan Kognitif (Cognitive Engagement)}

Dharmayana, dkk. (2012: 82), keterlibatan kognitif siswa terhadap sekolah adalah persepsi terhadap motivasi, usaha keras dan penggunaan strategi. Ini mencakup psikologis dalam belajar, usaha keras dalam belajar, keseriusan bersekolah keinginan bekerja melebihi yang dipersyaratkan, pilihan yang menantang, keluwesan dalam memecahkan masalah yang ada, dan memilih bekerja keras.

\section{Perilaku (Behavioral Engagement)}

Menurut Dharmayana, dkk.(2012: 82), keterlibatan perilaku yakni mengikuti setiap tata tertib dan peraturan disekolah.Perilaku yang positif, yaitu perilaku yang mengilustrasikan usaha, ketekunan, konsentrasi, perhatian, mengajukan pertanyaan, aktif dalm berdiskusi kelas, mengikuti aturan tata tertib, belajar, dan mampu menyelesaikan pekerjaan rumah.

Keluarga mempunyai pernanan yang sangat penting di dalam kegiatan siswa sebelum masuk ke dunia sekolah, orang tua akan memberitahu kewajiban seorang siswa di sekolah. Kasih sayang yang diberikan oleh kedua orang tua akan membuat anak merasa di perhatiin 
dan disayang dengan tulus. Sehigga ada salah satu orang tua yang tekah meninggal, seorang anak akan kehilangan kasih sayang serta perhatiann yang selama ini diberikan.

Hal ini sejalan dengan yang dimaksud dengan keluarga merupakan kelompok orangorang yang dipersatukan oleh ikatan-ikatan perkawinan, darah dan adopsi, yang membentuk satu rumah tangga saling berinteraksi dan berkomunikasi satu sama lain melalui peranperannya sendiri sebagai anggota keluarga dan mempertahankan kebudayaan masyarakat yang berlaku umum, atau menciptakan kebudayaan sendiri-sendiri Noorkasiani dkk, (2009: 148). Menurut Kartono (2014:57), keluarga merupakan unit sosial terkecil yang memberikan fondasi primer bagi perkembangan anak. Sedangkan lingkungan sekitar dan sekolah ikut memberikan nuansa pada perkembangan anak. Karena itu baik-buruknya struktur keluarga dan masyarakat sekitar memberikan pengaruh baik atau buruknya pertumbungan kepribadian anak.

Berdasarkan hasil penelitian yang dilakukan, kesimpulan yang diperoleh berdasarkan pengertian bimbingan kelompok. Menurut Sukardi (2008: 64), layanan bimbingan kelompok yaitu layanan bimbingan yang memungkinkan sejumlah peserta didik secara bersama-sama memperoleh berbagai baham dari nara sumber tertentu (terutama dari pembimbing/konselor) yang berguna untuk menunjang kehidupannya sehari-hari baik individu maupun sebagai pelajar, anggota keluarga dan masyarakat serta untuk pertimbangan dalam pengambilan keputusan.

Siswa yang mengikuti layanan bimbingan kelompok secara bersama-sama membahas tema pada setiap pertemuan. Tema-tema yang dibahas menunjang aktifisan disekolah terutama dalam aktifitas akademiknya.

Berdasarkan uji hipotesis yang dilakukan nilai $\mathrm{Z}=-2,805$ dan $\mathrm{p}<0,005$ yang artinya Ho ditolak dan Ha diterima. Sehingga ada keterlibatan akademik meningkat melalui layanan bimbingan kelompok pada siswa yatim atau piatu. Selain itu, tanda negatif yang terdapat pada nilai $\mathrm{Z}$ berarti terjadi peningkatan yang signifikan secara sebelum dan sesudah pemberian layanan bimbingan kelompok.

Hasil ini sejalan dengan teori yang pernah diteliti oleh Ayandi (2016: 10) yang menunjukkan bahwa adanya peningkatan keterlibatan akademik setelah diberikan layanan penguasaan konten. Hasil penelitian menunjukkan bahwa uji $t$, dengan nilai $t=-7,474$ dengan tingkat signifikan $\mathrm{p}=0,000(\mathrm{p}<0,05)$. Hasil penelitian ini menunjukkan bahwa manejemen 
diri terhadap keterlibatan akademik siswa tersebut menjadi lebih tinggi setelah mendapatkan layanan.

Berdasarkan penjabaran tersebut, perhatian anggota kelompok yaitu keterlibatan akademik pada siswa yatim atau piatu. Didalam pelaksanaanya, topik bahasan yang telah ditentukan berdasarkan yang dialami siswa didalam kegiatan belajar dan mengajar dilingkungan sekolah.

\section{Kesimpulan}

Tingkat keterlibatan akademik pada siswa yatim atau piatu sebelum diberikan layanan bimbingan kelompok yaituskor 69atau dengan kategori sedang.Tingkat keterlibatan akademik pada siswa yatim atau piatu setelah diberikan layanan bimbingan kelompok yaitu skor 94atau dengan kategori sangat tinggi.

Perbedaan skor antara pre-test dan post-test dikatakan signifikan karena taraf signifikan (2tailed) adalah 0,005 yang berarti lebih kecil $<0,005$. Hal ini dimaknai bahwa angka tersebut signifikan. Layanan bimbingan kelompok yang diberikan mampu merubah tingkat keterlibatan akademik pada siswa yatim atau piatu. Adanya pengaruh layanan bimbingan kelompok terhadap keterlibatan akademik pada siswa yatim atau piatu Dilihat dengan perhitungan statistik yang menunjukkan bahwa $Z=-2.805$ dan signifikan 0,005 Ha diterima dan Ho ditolak, sehingga dapat disimpulkan bahwa layanan bimbingan kelompok pengaruh terhadap keterlibatan akademik siswa yatim atau piatu di SMA Negeri 2 Kota Bengkulu.

\section{Daftar Pustaka}

Asmani, J. M. (2010). Bimbingan dan Konseling. Yogyakarta: Diva Press.

Ayandi, I. A. (2016). Pengaruh Layanan Penguasaan Konten Manajemen Diri Terhadap Keterlibatan Akademik Pada Siswa. (Skripsi tidak dipublikasikan). Program Studi Bimbingan dan Konseling FKIP Universitas Bengkulu, Bengkulu.

Dharmayana, I.W., Masrun., Amitya, K., \& Yapsir, G. W. (2012). Keterlibatan Siswa (Student Engagement) sebagai Mediaotor Kompetensi Emosi dan Prestasi Akademik. Jurnal Psikologi UGM, Yogyakarta. 39. (1). 76-94.

Fredericks, J. A., Blumenfeld, P.,\& Paris, A. (2004).School Engagements: Potential of the Concept, State of evidence. Review of Educational Research. 74. (1). 59-109.

Gerungan. (2004). Psikologi Sosial. Bandung: Refika Aditama.

Kartono, K. (2014). Patologi Sosial 2 Kenakalan Remaja. Jakarta: Raja Grafindo Persada. 
Noorkasiani., Paula, K., \& Mamah, S. (2009). Sosiologi Kebidanan. Jakarta: Trans Info Media.

Sardiman. (2011). Interaksi dan Motivasi Belajar Mengajar. Jakarta: Raja Grafindo.

Sugiyono. (2009). Statistika Untuk Penelitiaan. Bandung: Alfabeta.

Sukardi., Dewa, K., \& Kusmawati, N. (2008). Proses Bimbingan dan Konseling di Sekolah. Jakarta: Rineka Cipta.

Tohirin. (2015). Bimbingan dan Konseling di Sekolah dan Madrasah (Berbasis Integrasi). Jakarta: Raja Grafindo Persada.

Zuriah, N. (2009). Metodologi Penelitian Sosial dan Pendidikan. Jakarta: Bumi Aksara. 